\title{
Applying precision feeding to improve the nitrogen efficiency of swine production: a review of possible practices and obstacles
}

\author{
Alessandra Nardina Trícia Rigo Monteiro ${ }^{1}$ Teresinha Marisa Bertol ${ }^{2}$ Alexandre de Mello Kessler $^{3 *}$ \\ ${ }^{1}$ Departamento de Zootecnia, Universidade Estadual de Maringá (UEM), Maringá, PR, Brasil. \\ ${ }^{2}$ Embrapa Suínos e Aves, Concórdia, SC, Brasil. \\ ${ }^{3}$ Departamento de Zootecnia, Faculdade de Agronomia, Universidade Federal do Rio Grande do Sul (UFRGS), Avenida Bento Gonçalves, \\ 7712, 91540-000, Porto Alegre, RS, Brasil. E-mail: akessler@ufrgs.br. *Corresponding author.
}

\begin{abstract}
Optimizing nutrient efficiency is essential in order to increase sustainability of pig production systems, especially where the growing demand for food must be met at an affordable cost, without compromising environmental resources. To make this happen, it is necessary to develop efficient methods to accurately estimate the nutritional requirements of animals, as well as develop equipment and systems that allow for applying such expertise in the production system. Estimating the nutritional requirement of pigs through mathematical models, considering several factors that can impact the requirement, is a key factor to reduce the environmental load from pig production. Likewise, feed formulation and feeding programs, can help to achieve this. In this context, increasing the number of feeding phases in pig production, as well as precision feeding techniques, may be a tool to the esure adequacy of nutritional requirements, since its use can bring economic and environmental benefits. Key words: diet formulation, environmental impact, modelling, nutritional requirement, pig.
\end{abstract}

Aplicação da alimentação de precisão para melhorar a eficiência do nitrogênio na produção de suínos: revisão de possíveis práticas e obstáculos

RESUMO: Otimizar a eficiência nutricional é essencial para aumentar a sustentabilidade do sistema de produção de suínos, especialmente em um momento onde a crescente demanda por alimentos deve ser atendida a um custo acessivel, mas sem comprometer os recursos ambientais. Para tornar isso possível, é necessário o desenvolvimento de métodos eficientes e acurados para estimar as exigências nutricionais dos animais, bem como o desenvolvimento de equipamentos e sistemas que permitam aplicar esses métodos no sistema produtivo. Estimar as exigências nutricionais de suínos através de modelos matemáticos, considerando os vários fatores que impactam as exigências, pode ser um fator chave para reduzir a carga ambiental da suinocultura. Da mesma forma, formulações de rações e programas de alimentação podem auxiliar a alcançar isso. Neste contexto, o aumento do número de fases de alimentação na produção de suínos, bem como as técnicas de alimentação de precisão, podem ser ferramentas para a adequação das exigências nutricionais, uma vez que proporcionam beneficios econômicos e ambientais.

Palavras-chave: formulação de rações, impacto ambiental, modelagem, exigência nutricional, suíno.

\section{INTRODUCTION}

The swine production system has undergone huge advances in recent years, assuming great significance for the economy of several countries, such as in Brazil, the fourth largest producer and exporter of pork in the world (USDA, 2013). Increasing the efficiency of production systems, which reduces cost production, becomes more and more a factor of competitiveness and survival for companies and producer countries. Moreover, pressure from society to reduce the environmental impact of production has increased over time. Optimizing the efficiency of utilization of nutrients is essential for increasing production efficiency and to increase the sustainability of pig production, especially in a context where the growing demand for food can lead to increased competition for the use of resources. The challenge is to ensure different nutritional strategies for animals with different patterns of feed intake and lean deposition, in order to achieve the production and market demands. In this sense, nitrogen $(\mathrm{N})$ efficiency has become ever more important to achieve protein deposition and lower $\mathrm{N}$ excretion.

Nitrogen efficiency can be improved by the better adjustment of supplies to an individual pig's requirements (VAN MILGEN \& DOURMAD, 2015), thereby reducing fecal and urinary excretion. To achieve $\mathrm{N}$ efficiency, it is necessary to develop efficient methods to accurately estimate the 
nutritional requirements of animals, as well as the development of equipment and systems that allow for applying such expertise in the production chain, as precision feeding. This approach is based on the fact that animals within a herd differ from each other in terms of performance and, therefore, nutrient requirements (POMAR et al., 2013). Thus, the technique is providing, each day to each pig of the herd, the optimal concentration of nutrients.

According to POMAR et al. (2009), this could be achieved through (i) the real-time determination of individual nutrient requirements according to its actual body weight (BW) and actual growth and feed intake patterns, (ii) the formulation of balanced diets limiting the amount of excess nutrients (often two diets, one formulated to satisfy the requirements of the most demanding pig at the beginning of the first growing period and another to satisfy the less demanding pig at the end of the last growing period), and (iii) the adjustment of the dietary supply of nutrients that will match the evaluated requirements of each individual within the herd (through the daily blend of two diets, in order to achieve the nutrient requirement of each pig).

It is based on this background that the present review seeks assess the models used to estimate nutritional requirements and the methods for diet formulation, as well as to discuss the new approaches in swine nutrition and feeding related to precision feeding as a tool to enhance the $\mathrm{N}$ efficiency.

\section{Determination of nutritional requirements of pigs}

Several models have been proposed to estimate the nutritional requirement of pigs, and are classified as static or dynamic, empirical or mechanistic, and deterministic or stochastic. According to HAUSCHILD (2010), static models determine the animal's response under fixed conditions, while dynamic models consider time as an independent variable. Empirical model describes the quantitative responses of animals to a change in conditions (such as a change in diet), while the mechanistic model is based on the structure of a system, dividing it into its principal components. The deterministic model assumes definite predictions for quantities, while in the stochastic model random elements are part of the model and predictions have a distribution. Although all these models can be used in agricultural studies (THORNLEY \& FRANCE, 2007), most of them are dynamic, deterministic and mechanistic, such as the models proposed by BLACK et al. (1986), TMV (1991), INRAPORC (2006) and NRC (2012).
According SAKOMURA \& ROSTAGNO (2016), over several years, nutritional requirements were estimated by a dose-response method, an empirical approach that determines the requirements based on animal growth performance, in response to diets with increasing levels of the studied nutrient. However, mathematical models have been used to estimate the animal's growth since 1926, with the Gompertz function (WRIGHT, 1926). This model described the growth curve and body nutrient deposition, and also provided growth rates for body components such as fat, protein, water and ash, using allometric relations. Since then, other models such as the InraPorc software (INRAPORC, 2006) and the equations published by the National Research Council (NRC, 2012) have been developed. They are dynamic, because they estimate the animal's status over time, mechanistic by seeking to understand the mechanisms that lead the animal to a particular response and deterministic by estimating a single result from the description of an animal's profile (HAUSCHILD et al., 2010). In addition to growth, these models allow for estimating nutritional requirements and body composition, and moreover identify factors that affect the animal's performance.

For the InraPorc model, nutritional parameters as net energy (NOBLET et al., 1994), digestible amino acids (MOUGHAN, 2003) and ideal protein (VAN MILGEN et al., 2008), as well as the interactions between the dietary nutrients and between the diet and animal were taken into account. In addition, InraPorc determines an average animal profile in a population (BROSSARD et al., 2009), using model parameters related to feed intake and growth (VAN MILGEN et al., 2008). The InraPorc model is structurally very similar to that developed by Whittemore and Fawcett in 1974, where BW gain was modeled as a function of protein and lipid deposition (VAN MILGEN et al., 2013).

However, the software is designed for the ideal conditions for pig production, in which the ambient temperature is within the zone of thermal comfort. Meanwhile, the effect of ambient temperature has already been addressed in a recent publication, when a prediction model of nutrient utilization by sows was described, including this effect on sow and piglet performance (DOURMAD et al., 2015). According to these authors, the equations were incorporated into a simulation model including (i) a bioclimatic module, predicting the effect of outdoor temperature on the indoor temperature perceived by the sow, and (ii) a nutrition 
module, based on InraPorc, predicting the effect of temperature on feed intake, milk production, energy and amino-acid utilization, and body reserves.

Concerning the mathematical modeling approach described in the NRC (2012), there are three mathematical models, which are (i) for growingfinishing pigs between 20 and $140 \mathrm{~kg}$, (ii) for pregnant and (iii) for lactating sows, in order to estimate the SID amino acid requirements, $\mathrm{N}$, total digestible phosphorus (tract digestibility) and total calcium. Other requirements, such as vitamins, minerals and calcium, were estimated empirically and integrated into the model.

The model uses energy intake levels and performance, and from these inputs, it generates estimates of daily protein deposition, lipids deposition and changes in BW. It considers the thermal environment, but excludes other factors that could disrupt the system. Additionally, the NRC (2012) model assumes that the amino acid requirements increase with $\mathrm{BW}$ and slightly decrease with increases in maximum protein deposition (DE LANGE et al., 2012).

Traditionally, amino acid maintenance requirements have been related to the metabolic $\mathrm{BW}$ of pigs (i.e. $\mathrm{BW}^{0.75}$ ), as reported by the NRC (1998). However, this traditional approach ignores endogenous amino acid losses from the gut, which are the main contributor to maintenance amino acid requirements (DE LANGE et al., 2012). Moreover, it is known that dietary factors, such as the dry matter intake, also have an impact on amino acid maintenance requirements (MOUGHAN, 2003). These factors are all considered in the InraPorc and NRC (2012) models (Table 1), which express the amino acid requirements based on the coefficient of standardized ileal digestibility (SID), used to estimate the bioavailability of amino acids in swine feed ingredients (STEIN et al., 2007).

The modeling approach used by the NRC (2012) and InraPorc (VAN MILGEN et al., 2008) to estimate the requirements for essential amino acids and nitrogen considers as the main determinants the (i) basal endogenous gastrointestinal tract losses, which are related to feed intake, (ii) integument losses, as a function of $\mathrm{BW}^{0.75}$, (iii) potential of protein deposition and (iv) the efficiency of using SID amino acid ingested for each one of these functions (Table 1).

A specific equation was proposed by the NRC (2012) to calculate the efficiency of threonine utilization, considering that increased intake of fermentable fiber will reduce the post- absorptive efficiency of threonine utilization. Likewise, cysteine is considered a conditionally essential amino acid and can be synthesized from methionine only. Thus, both models showed values of nutritional requirements only for methionine and methionine plus cysteine. Arginine; however, can be synthetized by the animal (WU et al., 2007). For this, the efficiency for arginine utilization exceeds $100 \%$ in the InraPorc model (Table 1), since pigs can synthesize this amino acid, but the synthesis capacity may be insufficient to support the maximum growth (VAN MILGEN et al., 2013).

Another point of the NRC (2012) model is that it considers that, with an increase in the pig's age, increasing competition occurs for aromatic amino acids with branched-chain amino acids (BCAA) like leucine, isoleucine and valine. Since the major fraction of ingested BCAA is not metabolized by the liver, their plasma concentrations are quickly elevated, increasing their uptake in the brain, and decreasing the brain uptake and levels of aromatic amino acids like tryptophan (FERNSTROM, 2005). For this reason, the model suggested that the requirement of SID tryptophan increases over time, i.e. it is $16.2 \%$ of lysine for young pigs from 11 to $25 \mathrm{~kg}, 17.3 \%$ for growing pigs from 50 to $75 \mathrm{~kg}$ and $17.8 \%$ for late finishing pigs (from 100 to $135 \mathrm{~kg}$ ).

Although models provide the more accurate estimation of the amino acid requirements, DE LANGE et al. (2012) described three limitations in those estimates, i.e.: (i) effects of compensatory growth on amino acid requirements are not considered; (ii) models cannot be used to assess the marginal response to varying amino acid intake levels and; therefore, to conduct cost-benefit analyses; and (iii) the effect of differences in between-animal variability is not considered.

Though there are still limitations in the use of models to estimate nutritional requirements, some studies that compare requirements estimated by models with standard recommendations have shown that models can predict the pig's requirement more accurately than dose-response methods. In this sense, MONTEIRO et al. (2017) formulated two diets for growing-finishing pigs (from 30 to $130 \mathrm{~kg}$ ); one was adjusted by using the InraPorc model to reduce nutrient levels, and another used standard nutritional levels (ROSTAGNO et al., 2011). The authors did not find any differences in performance, carcass traits or meat quality. However, pigs fed with the adjusted diet showed less $\mathrm{N}$ intake $\left(7.48 v s .6 .30 \mathrm{~kg} \mathrm{pig}^{-1}\right)$ and $\mathrm{N}$ excretion (4.74 vs. $\left.3.60 \mathrm{~kg} \mathrm{pig}^{-1}\right)$ when compared with pigs fed with the standard recommendations. Besides, 
Table 1 - Estimated amino acids and nitrogen requirements for various biological functions, including whole body protein deposition (PD) for growing-finishing pigs, according InraPorc and National Research Council (NRC, 2012) models.

\begin{tabular}{|c|c|c|c|c|c|c|c|c|}
\hline & \multicolumn{2}{|c|}{ Intestinal losses } & \multicolumn{2}{|c|}{ Integument losses } & \multicolumn{2}{|c|}{$\begin{array}{l}\text { Maximum efficiency of } \\
\text { amino acid utilization }\end{array}$} & \multicolumn{2}{|c|}{ Content in $\mathrm{PD}^{2}$} \\
\hline & \multicolumn{2}{|c|}{---( $\mathrm{g} \mathrm{kg}^{-1} \mathrm{DM}$ intake)--- } & \multicolumn{2}{|c|}{$\left(\mathrm{mg} \mathrm{kg}^{-1}\right.$ body weight $\left.{ }^{0.75} \mathrm{~d}^{-1}\right)$} & \multicolumn{2}{|c|}{-----------(\%)----------- } & \multicolumn{2}{|c|}{---(g $100 \mathrm{~g}^{-1}$ lysine $)--$} \\
\hline & InraPorc & $\mathrm{NRC}$ & InraPorc & NRC & InraPorc $^{2}$ & NRC & InraPorc & $\mathrm{NRC}^{3,4}$ \\
\hline Lysine & 0.313 & 0.417 & 4.50 & 4.50 & 72.0 & 75.0 & 100 & 100 \\
\hline Methionine & 0.087 & 0.114 & 1.00 & 1.05 & 64.0 & 73.0 & 27.0 & 27.9 \\
\hline Methionine + Cystine & 0.227 & 0.212 & 5.70 & 4.71 & 51.0 & 60.3 & 41.8 & 41.8 \\
\hline Threonine ${ }^{5}$ & 0.330 & 0.605 & 3.30 & 3.35 & 61.0 & 78.0 & 53.2 & 53.1 \\
\hline Tryptophan & 0.117 & 0.133 & 0.90 & 0.94 & 57.0 & 61.0 & 13.6 & 12.8 \\
\hline Isoleucine & 0.257 & 0.383 & 2.50 & 2.51 & 67.0 & 76.0 & 49.7 & 50.8 \\
\hline Leucine & 0.427 & 0.525 & 5.30 & 5.23 & 76.0 & 75.1 & 103.0 & 100 \\
\hline Valine & 0.357 & 0.514 & 3.80 & 3.77 & 71.0 & 80.0 & 67.1 & 66.2 \\
\hline Phenylalanine & 0.273 & 0.343 & 3.00 & 3.03 & 82.0 & 67.1 & 54.3 & 52.2 \\
\hline Phenylalanine + Tyrosine & 0.497 & 0.284 & 4.90 & 1.89 & 75.0 & 74.6 & 95.4 & 89.9 \\
\hline Histidine & 0.130 & 0.203 & 1.30 & 1.26 & 93.0 & 100 & 40.1 & 45.2 \\
\hline Arginine & 0.280 & 0.485 & - & - & 154 & 147 & 89.9 & 90.2 \\
\hline Nitrogen $\times 6.25$ & 8.52 & 14.1 & 104 & 105 & 81.0 & 85.0 & - & - \\
\hline
\end{tabular}

${ }^{1}$ Utilization for maintenance. ${ }^{2}$ The maximum efficiencies are calculated from the hypothesis that the ideal amino acid profile is correct for a pig weight $55 \mathrm{~kg}$, consuming $1625 \mathrm{~g}$ of feed per day and with an average daily gain of $650 \mathrm{~g} . \mathrm{d}^{-1}$ (VAN MILGEN et al., 2008). ${ }^{3}$ Standardized ileal digestible amino acid intake requirements for PD of individual growing pigs in a relatively disease and stress-free environment (NRC, 2012). ${ }^{4} \mathrm{~A}$ different content of amino acids in PD is assumed for ractopamine induced PD (NRC, 2012). ${ }^{5}$ For threonine, utilization efficiencies applied to diets containing $0 \%$ of fermentable fibre.

the feed cost was $6.82 \%$ lower for animals that were fed diets with adjusted nutritional levels.

However, the above mentioned study estimated the nutritional requirements, by using models, to an average population and not to each pig within a herd. It seems to indicate that the use of precision feeding techniques could provide even better results.

\section{Feed formulation to lowering nitrogen excretion}

Until the 1970 s, the feed formulation was determined using trial and error methods, Pearson Square and algebraic equations (BARIONI et al., 2003). Development of linear programming for feed formulation allowed for the efficient incorporation of economic criteria into the formulation software (SCOTT, 1972). This method consisted of determining the inclusion level of an ingredient in the diet in order to minimize or maximize an objective function, which is nowadays the feed cost (HAUSCHILD, 2010).

While it is widely used by industry, this model has low flexibility and does not take into account the animal effect, assuming that all individuals exhibit the same responses. Therefore, new approaches are being studied, such as the utilization of linear constraints for minimizing other functions, like the environmental impact, due to growing concerns about environmental integrity.

The research project developed by JEAN DIT BAILLEUL et al. (2001) and POMAR et al. (2007) used a multiobjective optimization method based on linear programming for low cost formulation, with an objective function composed of economic terms and nutrient excess. The authors combined the low feed cost with the reduction of $\mathrm{N}$ and phosphorus excretion, showing that nutrition can be a key factor to reduce the environmental burden of pig production.

In this sense, dietary crude protein (CP) reduction through balancing the diet with industrial amino acids is an effective way of reducing $\mathrm{N}$ excretion, as well as $\mathrm{N}$ emissions, as long as pig performance and carcass composition are not adversely affected, as reviewed by DOURMAD \& JONDREVILLE (2007). Authors considered that an improvement in $\mathrm{N}$ efficiency and consequently a reduction in $\mathrm{N}$ excretion could be obtained through a combination of different protein sources and/ or the substitution of protein by inclusions of free amino acids, as well as when multiphase feeding is 
combined with a perfect balance between essential amino acids, and with optimizing the supply of nonessential amino acids.

For this reason, precision feeding techniques have come under increasing study in recent years, and some researches have been conducted on the swine production chain (HAUSCHILD et al., 2012; POMAR et al., 2014; ANDRETTA et al., 2014, 2016; MONTEIRO et al., 2016).

New feeding practices toward nitrogen efficiency in pigs Usually, the nutrient density progressively decreases with an increase in the pig's body weight. Therefore, the optimal concentration of nutrients in the diet also decreases over time. One way to adjust the dietary concentration of nutrients to match the animal's requirements is to increase the number of feeding phases (Figure 1). These schemes are commonly used to accommodate continuous changes in the amino acid requirements of growing pigs, and the environmental benefits of this strategy have been demonstrated (POMAR et al., 2009; POMAR et al., 2014). However, the use of several diets increases the cost of feed management and facilities. Based on this premise, FEDDES et al. (2000) developed a system with the automatic blending and distribution of two diets combined in variable proportions, which can meet the requirements of pigs throughout their growing period (POMAR et al., 2014). The diets are formulated to meet the pig's nutritional requirements at the beginning and at the end of growth period.

POMAR et al. (2014) formulated two diets, one of them meeting the pig's nutritional requirements at the beginning of the growing period (high nutrient concentration) and the other meeting the requirements at the end of this period (low concentration). They commingled diets in different proportions, according to the three-phase (3P) or daily feeding program, in order to meet the nutritional requirements at the beginning of each feeding stage. The group of pigs receiving the daily feeding program consumed $7.3 \%$ less protein than the group fed the $3 \mathrm{P}$, as a result of the progressive decrease in the amount of protein released during the course of the experiment (Figure 2). Replacing the traditional 3P method with the daily feeding program reduced the intake and excretion of nitrogen by $7.3 \%$ and $12 \%$, respectively.

However, current group phase-feeding programs do not account for the variation among individuals, and the diets are usually formulated to optimize the population performance, with most of the pigs receiving more nutrients than they actually need (HAUSCHILD et al., 2010). While promoting better nutrient use, they fail to provide exactly what each animal requires. In this context, precision feeding is a modern approach in which pigs are fed individually using diets adjusted in real time according to their patterns of feed intake and growth (HAUSCHILD et al., 2012).

For this purpose, HAUSCHILD et al. (2012) developed and evaluated a mathematical model used to estimate the daily amino acid requirements of individual growing-finishing pigs. The empirical component was used to estimate, in real time, the nutrient requirements for each pig. Based on these estimates, the mechanistic component uses classic factorial equations to estimate the optimal concentration of amino acids that must be offered to each pig to meet its requirements. The authors also evaluated the precision of the proposed model by comparing its estimates with those generated by the InraPorc model. They considered that the mechanistic model component estimated the optimal SID lysine to net energy ratio with reasonable variation between animal and overtime, with an average variation coefficient of 7 and 14\%, respectively. Thus, they concluded that the model makes it possible to dynamically estimate the amino acids requirements of each pig.

Furthermore, the limitation related to the effect of between-animal variability on determining amino acids requirements has been approached by the application of precision feeding principles. ANDRETTA et al. (2014) evaluated the impact of moving from a conventional system to a precision feeding system (multiphase individual (MPI) feeding) on performance and dietary nutrient utilization in growing-finishing pigs. During the overall trial, they observed that the systems had similar values of feed intake, weight gain, feed conversion ratio and $\mathrm{N}$ and phosphorus retention. In the same way, there was no difference in carcass characteristics and in the weight of the main cuts. However, compared with the 3P program, the MPI feeding led to a reduction in lysine intake by $27 \%$, and $\mathrm{N}$ and phosphorus excretion reduced by $22 \%$ and $27 \%$, respectively, as a result of improved efficiency in terms of $\mathrm{N}$ and phosphorus retention (Figure 2).

In a more recent study, ANDRETTA et al. (2016) evaluated pig performance and nutrient balance during the growing finishing period, switching from conventional feeding to MPI in which pigs were fed individually with daily tailored diets. They observed that $\mathrm{N}$ excretion was reduced by $23 \%$ in MPI- $110 \%$ (feed adjusted daily to match 


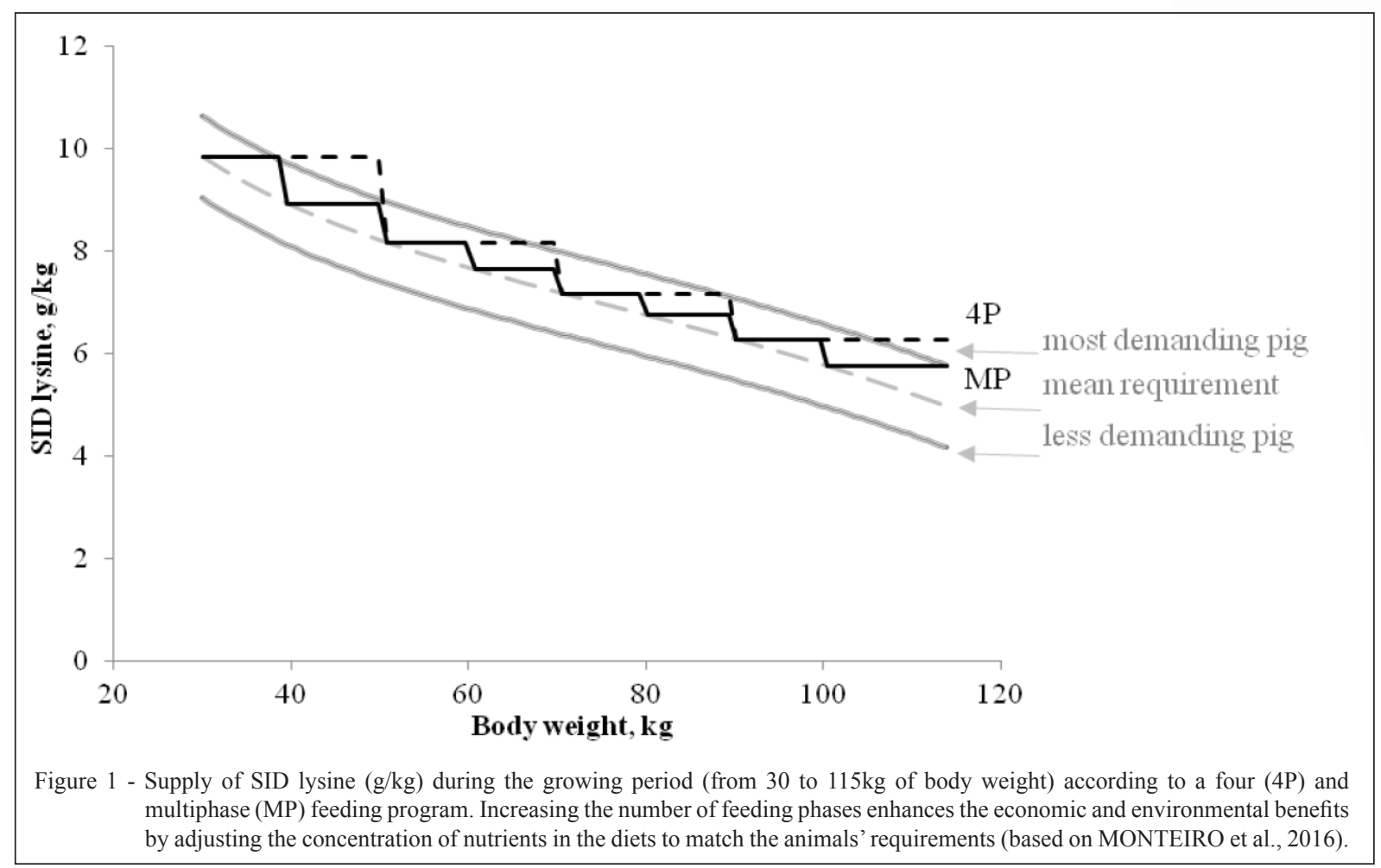

$110 \%$ of the estimated nutrient requirements of each individual pig.) in comparison with the $3 \mathrm{P}$ treatment (Figure 2). This represented a reduction in $\mathrm{N}$ excretion by about $12 \%$ for each percentage unit of dietary CP. The environmental impact of pig fattening by comparing different feeding programs (different numbers of feeding phases and individual daily feeding) was evaluated by MONTEIRO et al. (2016). They reported that N retention efficiency increased from $32 \%$ for two phases feeding without amino acids up to $47 \%$ for MPI and the low CP diet. These authors also reported that, for each percentage unit of dietary $\mathrm{CP}$ reduced, $\mathrm{N}$ excretion was reduced by $16 \%$, in comparison with two phase feeding and MPI.

Other studies also observed that average dietary $\mathrm{CP}$ concentration over the growing-finishing period was reduced when the number of feeding phases increased, or with the use of precision feeding techniques (ANDRETTA et al., 2014, 2016; MONTEIRO et al., 2016). These reductions in $\mathrm{N}$ excretion obtained by feeding pigs using MPI was a result of the reduction in $\mathrm{N}$ supply due to the increased number of feeding phases (i.e. daily phases) and the concomitant adjustment of the supply to meet requirements (ANDRETTA et al., 2016), without compromising pig performance or carcass characteristics (POMAR et al., 2014; ANDRETTA et al., 2014, 2016; MONTEIRO et al., 2016).

In this context, the precision feeding program showed advantages compared to phase feeding, and was a way to allow animals to be managed as independent individuals in the group (WATHES et al., 2008), while reducing $\mathrm{N}$ excretion. The implementation of precision feeding programs in practice is still a significant challenge. However, it is expected that this technique could be available soon as a sustainable tool to increase the competitiveness and reduce environmental impact of the pig industry (ANDRETTA et al., 2014).

\section{CONCLUSION}

The studies and the development of new formulation methods to increase the efficiency of use of nutrients and to reduce nitrogen excretion by pigs, since they are cost-effective and applicable, are essential to achieve a more precise nutrition. Modeling animal nutrition has been effective to estimate growth and nutritional requirements, and since these methods are increasingly being discussed and refined, the trend is that they will be increasingly used in assessing pig nutrition. There is a strong need for developing 


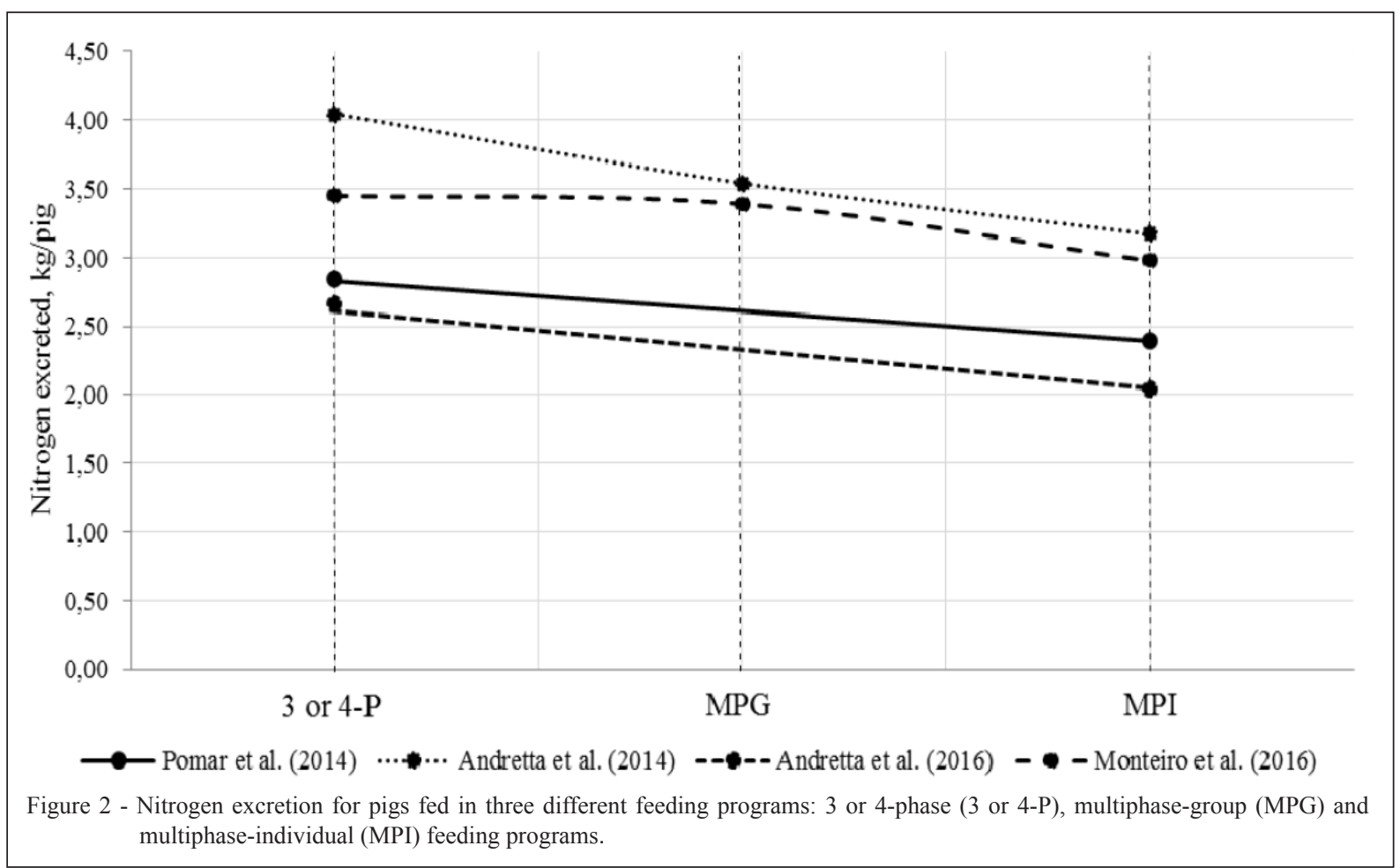

models that best describe the animal growth trajectory, the physiological conditions in terms of lean and fat body masses, as well as the rate and efficiency of nutrient deposition that better reflect the changes in the digestive and metabolic phenomena in pigs.

However, due to the importance of considering between-animal variation, stochasticity has been included in some modelling approaches to study the impact of changes in this factor on performance. This seems to indicate that, in the near future, we could have models capable of evaluating how the whole population responds to different management practices. Moreover, precision feeding can be a tool to assess the adequacy of nutritional requirements, since its use can bring economic and environmental benefits, through, the feeding applied to an individual and not to groups. However, the implementation of precision feeding systems presents significant challenges which are related to their complexity, reliability and cost effectiveness. Nevertheless, in some countries, the development of sustainable precision livestock farming is a vision for the future of the swine industry. Therefore, since this feeding approach is still being developed and refined, it is expected to be available soon as a sustainable tool to increase the competitiveness of the pig industry.

\section{REFERENCES}

ANDRETTA, I. et al. Precision feeding can significantly reduce lysine intake and nitrogen excretion without compromising the performance of growing pigs. Animal, v.10, p.1137-1147, 2016. Available from: $<$ https://www.ncbi.nlm.nih.gov/pubmed/26759074>. Accessed: Dec. 07, 2016. doi: 10.1016/j.agee.2004.05.007.

ANDRETTA, I. et al. The impact of feeding growing-finishing pigs with daily tailored diets using precision feeding techniques on animal performance, nutrient utilization, and body and carcass composition. Journal of Animal Science, v.92, n.11, p.39253936, 2014. Available from: <https://www.ncbi.nlm.nih.gov/ pubmed/25057024>. Accessed: Dec. 08, 2016. doi: 10.2527/ jas.2014-7643.

BLACK, J.L. et al. Simulation of energy and amino acid utilisation in the pig. Reserach and Development in Agriculture, v.3, p.121145, 1986. Available from: <http://agris.fao.org/agris-search/ search.do?recordID=US201301433133>. Accessed: Oct. 09, 2015.

BROSSARD, L. et al. Modelling the variation in performance of a population of growing pig as affected by lysine supply and feeding strategy. Animal, v.3, p.1114-1123, 2009. Available from: $<$ https:// www.ncbi.nlm.nih.gov/pubmed/22444841>. Accessed: Nov. 12, 2016. doi: 10.1017/S1751731109004546.

DE LANGE, C.F.M. et al. Amino acid nutrition and feed efficiency. In: PATIENCE, J.F. (Ed.). Feed efficiency in swine. Netherlands: Wageningen Academic, 2012. 264p. Available from: $<$ link.springer.com/chapter/10.3920\%2F978-90-8686-756-1_4>. Accessed: Jan. 18, 2015. doi: 10.3920/978-90-8686-756-1. 
DOURMAD, J.-Y. et al. Influence de la température ambiante chez la truie allaitante, une approche par méta-analyse et modélisation. In: JOURNEES RECHERCHE PORCINE, 2015, Paris, França. Proceedings... Paris: Journees Recherche Porcine, 2015. V.47, p.105-110.

DOURMAD, J.-Y.; JONDREVILLE, C. Impact of nutrition on nitrogen, phosphorus, $\mathrm{Cu}$ and $\mathrm{Zn}$ in pig manure, and on emissions of ammonia and odours. Livestock Science, v.112, p.192-198, 2007. Available from: <http://www.sciencedirect.com/science/article/pii/ S1871141307004684>. Accessed: Apr. 22, 2015. doi: 10.1016/j. livsci.2007.09.002.

FEDDES, J.J.R. et al. A system for providing protein for pigs in intermediately sized grower/finisher barns. Canadian Agricultural Engineering, v.42, n.4, p.209-213, 2000. Available from: <http://www.csbe-scgab.ca/docs/journal/42/42_4_209_ocr. pdf $>$. Accessed: Apr. 10, 2016.

FERNSTROM, J.D. Branched-chain amino acids and brain function. Journal of Nutrition, v.135, n.6, p.1539S-1546S, 2005. Available from: $<$ https://www.ncbi.nlm.nih.gov/pubmed/15930466>. Accessed: Mar. 24, 2015.

HAUSCHILD, L. et al. Development of sustainable precision farming systems for swine: estimating real-time individual amino acid requirements in growing-finishing pigs. Journal of Animal Science, v.90, n.8, p.2255-2263, 2012. Available from: $<$ https://www. animalsciencepublications.org/publications/jas/pdfs/90/7/2255>. Accessed: May 17, 2014. doi: 10.2527/jas.2011-4252.

HAUSCHILD, L. et al. Systematic comparison of the empirical and factorial methods used to estimate the nutrient requirements of growing pigs. Animal, v.4, p.714-723, 2010. Available from: <www.ncbi.nlm.nih.gov/pubmed/22444124>. Accessed: Jan. 06, 2014. doi: 10.1017/S1751731109991546.

HAUSCHILD, L. Modelagem individual e em tempo real das exigências nutricionais de suínos em crescimento. 2010.142f. $\mathrm{PhD}$ Thesis (Animal Science) - Universidade Federal de Santa Maria, RS.

INRAPORC. Un outil pour évaluer des stratégies alimentaires chez le porc. Paris: Institut National de la Recherche Agronomique, 2006. Available from: $<$ https://inraporc.inra.fr/inraporc/>. Accessed: Feb. 17, 2015.

JEAN DIT BAILLEUL, P., et al. Reducing nitrogen excretion in pigs by modifying the traditional least-cost formulation algorithm. Livestock Production Science, v.72, n.3, p.199-211, 2001. Available from: <www.sciencedirect.com/science/article/pii/S030162260100224X>. Accessed: Oct. 16, 2014. doi: 10.1016/S0301-6226(01)00224-X.

MONTEIRO, A.N.T.R. et al. Effect of feeding strategy on environmental impacts of pig fattening in different contexts of production: evaluation through life cycle assessment. Journal of Animal Science, v.94, p.4832-4847, 2016. Available from: $<$ https:// www.ncbi.nlm.nih.gov/pubmed/27898927>. Accessed: Nov. 20, 2016. doi: $10.2527 /$ jas.2016-0529.

MONTEIRO, A.N.T.R. et al. The impact of feeding growing-finishing pigs with reduced dietary protein levels on performance, carcass traits, meat quality and environmental impacts. Livestock Science, v.198, p.162-169, 2017. Available from: <http://www.sciencedirect.com/ science/article/pii/S1871141317300525>. Accessed: Apr. 15, 2017. doi: 10.1016/j.livsci.2017.02.014
MOUGHAN, P.J. Amino acid availability: aspects of chemical analysis and bioassay methodology. Nutrition Research Reviews, v.16, n.2, p.127-141, 2003. Available from: <https://www.ncbi. nlm.nih.gov/pubmed/19087386>. Accessed: Jan. 06, 2014. doi: 10.1079/NRR200365.

NOBLET, J. et al. Prediction of net energy value of feeds for growing pigs. Journal of Animal Science, v.72, n.2, p.344-354, 1994. Available from: < https://www.ncbi.nlm.nih.gov/pubmed/8157519>. Accessed: Mar. 16, 2015.

NRC (NATIONAL RESEARCH COUNCIL). Nutrient requirements of swine. 10.ed. Washington: National Academic, 1998. 210p.

NRC (NATIONAL RESEARCH COUNCIL). Nutrient requirements of swine. 11.ed. Washington: National Academic, 2012. 420p.

POMAR, C. et al. Applying precision feeding techniques in growing-finishing pig operations. Revista Brasileira de Zootecnia, v.38, p.226-237, 2009. Available from: <http:/www.scielo.br/ scielo.php?script=sci_arttext\&pid=S1516-35982009001300023>. Accessed: June 26, 2015. doi: 10.1590/S1516-35982009001300023.

POMAR, C. et al. Estimating real-time individual amino acid requirements in growing-finishing pigs: towards a new definition of nutrient requirements in growing-finishing pigs? In: INTERNATIONAL SYMPOSIUM: MODELLING IN PIG AND POULTRY PRODUCTION, 2013, Jaboticabal, SP. Proceedings... Jaboticabal: FUNEP, 2013. p.1-19.

POMAR, C. et al. Reducing phosphorus concentration in pig diets by adding an environmental objective to the traditional feed formulation algorithm. Livestock Science, v.111, n.1-2, p.16-27, 2007. Available from: <http://www.sciencedirect.com/science/ article/pii/S1871141306004161>. Accessed: Aug. 23, 2016.

POMAR, C. et al. The impact of daily multiphase feeding on animal performance, body composition, nitrogen and phosphorous excretions, and feed costs in growing-finishing pigs. Animal, v.8, p.704-713, 2014. Available from: <http://www.ncbi.nlm.nih.gov/pubmed/24739349>. Accessed: Oct. 06, 2014. doi: 10.1017/S1751731114000408.

ROSTAGNO, H.S. et al. Tabelas brasileiras para aves e suínos: composição de alimentos e exigências nutricionais. Viçosa: UFV, 2011. 252p.

SAKOMURA, N.K.; ROSTAGNO, H.S. Métodos de pesquisa em nutrição de monogástricos. Jaboticabal: Funep, 2016. 2v.

SCOTT, J.T.; BROADBENTO, E.E. A computerized cattle feeding program for replacement and ration formulation. Illinois Agricultural Economics, v.2, n.2, p.16-25, 1972. Available from: <https://www. jstor.org/stable/1349054?seq=1\#page_scan_tab_contents $>$. Accessed: Jan. 11, 2015.

STEIN, H. et al. Amino acid availability and digestibility in pig feed ingredients: Terminology and application. Journal of Animal Science, v.85, p.172-180, 2007. Available from: <https://www. ncbi.nlm.nih.gov/pubmed/17179553>. Accessed: Nov. 18, 2015.

THORNLEY, J.H.M.; FRANCE, J. Mathematical models in agriculture. Quantitative methods for the plant, animal and ecological sciences. 2.ed. Wallingford: CABI, 2007. 928p. Available from: <http://www.cabi.org/ bookshop/book/9780851990101>. Accessed: Jan. 12, 2017. 
TMV (TECHNISH MODEL WARKENSVOEDING). Werkgroep informatiemodel. Rosmalen, GER: Research Institute for Pig Husbandry, 1991. Report P1.117.

USDA, 2013. Livestock and poultry: world markets and trade. 2014: record global meat trade. Available from: <http://apps.fas.usda.gov/ psdonline/circulars/livestock poultry.pdf $>$. Accessed: Sept. 20, 2016.

VAN MILGEN, J. et al. InraPorc: a model and decision support tool for the nutrition of growing pigs. Animal Feed Science and Technology, v.143, n.1-4, p.387-405, 2008. Available from: $<$ http:// www.sciencedirect.com/science/article/pii/S0377840107001782>. Accessed: Dec. 29, 2016. doi: 10.1016/j.anifeedsci.2007.05.020.

VAN MILGEN, J. et al. InraPorc: where do we come from and where do we want to go? In: INTERNATIONAL SYMPOSIUM: MODELLING IN PIG AND POULTRY PRODUCTION, 2013 , Jaboticabal, SP. Proceedings... Jaboticabal: FUNEP, 2013. p.1-17.

VAN MILGEN, J.; DOURMAD, J.-Y. Concept and application of ideal protein for pigs. Journal of Animal Science and Biotechnology, v.6, p.1-11, 2015. Available from: <https://www. ncbi.nlm.nih.gov/pubmed/25937926>. Accessed: Jan. 02, 2017. doi: 10.1186/s40104-015-0016-1.
WATHES, C.M. et al. Is precision livestock farming an engineer's daydream or nightmare, an animal's friend or foe, and a farmer's panacea or pitfall? Computers and Electronics in Agriculture, v.64, p.02-10, 2008. Available from: <http://www.sciencedirect. com/science/article/pii/S0168169908001476>. Accessed: Feb. 20, 2017. doi:10.1016/j.compag.2008.05.005.

WHITTEMORE, C.T.; FAWCETT, R.H. Model responses of the growing pig to the dietary intake of energy and protein. Animal Production, v.19, p.221-231, 1974. Available from: <http:// journals.cambridge.org/article S0003356100022789>. Accessed: Mar. 12, 2017.

WRIGHT, S. The biology of population growth: the natural increase of mankind - reviews. Journal of the American Statistica Association, v.21, p.493-497, 1926. Available from: <https:// www.jstor.org/stable/2276990?seq=1\#page_scan_tab_contents $>$. Accessed: Jan. 06, 2014.

WU, G. et al. Important roles for the arginine family of amino acids in swine nutrition and production. Livestock Science, v.112, n.8-22, p.8-22, 2007. Available from: <http:/www.sciencedirect. com/science/article/pii/S1871141307004179>. Accessed: Mar. 12, 2017. doi: 10.1016/j.livsci.2007.07.003. 